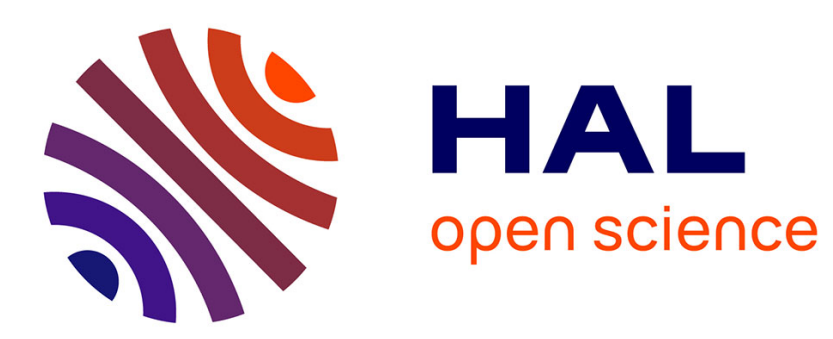

\title{
French vertical-flow constructed wetlands in mountain areas: how do cold temperatures impact performances?
}

S. Prost Boucle, O. Garcia, Pascal Molle

\section{To cite this version:}

S. Prost Boucle, O. Garcia, Pascal Molle. French vertical-flow constructed wetlands in mountain areas: how do cold temperatures impact performances?. Water Science and Technology, 2015, 71 (8), pp.1219-1228. 10.2166/wst.2015.074 . hal-01242871

\section{HAL Id: hal-01242871 \\ https://hal.science/hal-01242871}

Submitted on 14 Dec 2015

HAL is a multi-disciplinary open access archive for the deposit and dissemination of scientific research documents, whether they are published or not. The documents may come from teaching and research institutions in France or abroad, or from public or private research centers.
L'archive ouverte pluridisciplinaire HAL, est destinée au dépôt et à la diffusion de documents scientifiques de niveau recherche, publiés ou non, émanant des établissements d'enseignement et de recherche français ou étrangers, des laboratoires publics ou privés. 


\title{
French vertical-flow constructed wetlands in mountain areas: how do cold temperatures impact performances?
}

\author{
Prost-Boucle S. ${ }^{\text {a }}$, Garcia O. ${ }^{\mathrm{a}}$, Molle P. ${ }^{\mathrm{a}}$

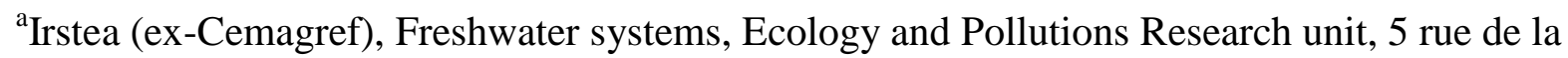 \\ Doua - CS70077, 69626 Villeurbanne, FRANCE (stephanie.prost-boucle@irstea.fr)
}

\begin{abstract}
French version of Vertical flow constructed wetlands (VFCW) is characterized by treating directly raw wastewater on the first stage filter. VFCW is a well-developed technology with more than 3,500 plants in operation in France. However, VFCW performance may be affected under low temperatures reached in mountain areas during winter. The effect of cold conditions over 12 plants, ranged from 75 to 1,900 p.e. and from 680 to 1,500 m a.s.1., was studied during two years.

The plant hydraulic loads, air and filter temperatures were continuously measured. Additionally, 24-hours flow proportional samples, at each stage of treatment, were conducted in summer (as a reference) and winter. Online measurements of ammonium and nitrates were also analyzed to describe the nitrogen removal dynamics.

Since no impact on COD, BOD and SS removal was observed, the effect of cold temperatures over nitrification was further analyzed. Nitrogen removal was relatively unaffected during winter season. Only significant effects were confirmed over the second stage for loads above $10 \mathrm{gTKN} / \mathrm{m}^{2} / \mathrm{d}$. Temperatures profiles allowed to analyze the filter buffer capacity in terms of freezing. Under minimal air temperature of $-19^{\circ} \mathrm{C}$, no critical operation was observed, although design and operation recommendations can be provided to ensure suitable plant performances.
\end{abstract}

\section{KEYWORDS}

Cold climate, nitrification, temperature, vertical flow constructed wetlands.

\section{INTRODUCTION}

French-system vertical flow constructed wetlands (VFCW) directly treat raw wastewater on the first-stage filters. They are extensively developed, with about 3,500 plants in operation in France. The French VFCW system consists in two successive VFCW stages-the first filled with gravel and the second filled with sand (see Mole et al., 2005, for media description). The first stage is split into 3 filters, while the second stage is split into 2 filters. Alternation is done twice a week every 3-4 days.

When VFCW are set up in mountain areas, cold temperatures become an important issue for filter function (freeze-up of the filter, the sludge layer, the distribution pipes...) and performances (mainly nitrification). In very cold climate zones, ice can form when water temperature nears $2^{\circ} \mathrm{C}$ (Kadlec, 2001). In rural area this can be counterbalanced when sewers are short by relatively 'warm' wastewater that hinder filter's freezing. Nevertheless, a swift and intense freeze could form ice over the surface or even freeze up the filter in depth. Besides, the dynamic of the freeze can impact the ice formation. Indeed, as heat transfers in filters essentially take place vertically and only negligibly horizontally (Kadlec, 2001), some authors (Bronfenbrener \& Bronfenbrener, 2010) observed that slow freeze tends to transfer moisture towards the frozen zone (i.e. the filter surface). Many factors can impact the freezing dynamic as the free water content which promotes heat losses through evaporation (Wallace et al., 2011) and the presence of ice cover (with a 4-times higher thermal conductivity than water) which adds further net heat losses and further risk of filter freeze-up. 
However, ice struggles to form when there is snow or mulch (Kadlec, 2001), as snow-once deep enough-effectively provides a degree of insulation. McCarthy et al. (1997) reported (in Northern Minnesota, USA) a case of filter freeze-up without snow cover whereas the filters had not frozen up in previous years when under snow. Consequently, experiments have been done with thatch and mulch layers to provide the filters with surface insulation (Smith et al., 1997; Wallace et al., 2011) reporting that a $20 \mathrm{~cm}$-deep thatch layer effectively helps minimizing heat losses, but hinder oxygen transfer inside the filter matrix. This affected performances (especially on nitrification). When designing system for cold climate it is relevant to use basic design strategies (Wallace et al., 2011) to avoid heat loss to the atmosphere. For example, installing smaller particle size can help to slower cooldown (Smith et al., 1997). As well, adapt operation strategy (alternation frequency, batches frequency) is a way to shield the filters from freezing. A key factor to bear in mind is that high-altitude villages already have to contend with winter-round accessibility issues due to road ice and typically heavily snowfalls, which leads to postpone operation necessities on the treatment plant due to higher priority tasks. Consequently, implementation of automatic operation (screening, filter's alternation) is a good solution to ensure operational functions and diminish heat losses.

In France, 341 VFCW designed for a capacity of 20 to 1950 person-equivalents are implemented in mountain area at altitude from 500 to $1,500 \mathrm{~m}$. Feedback of operation and performance problems that might occur in winter is not known. Consequently, water authorities backed a research programme to determine the altitude threshold upwards of which VFCW lose applicability or require specific adaptations. This paper reports the findings of a national-scale study led on 12 mountain-zone-based VFCW ranged from 70 to 1,900 p.e. and 680 to $1,500 \mathrm{~m}$ a.s.l. in altitude over a two-year period (2012-2014). As freezing temperatures can have different effects on VFCW systems according to the maturity of the filters (deposit layer depth), type of distribution systems or sewer scheme (combined or separate), a treatment plant selection has been done to cover a panel of critical situations. Since Molle et al. (2008) had demonstrated how total nitrogen was sensitive to lowtemperature conditions, a specific attention is done on nitrification, considered as a good indicator to temperature sensitivity.

\section{MATERIAL AND METHODS}

\section{VFCW selection process and characteristics}

VFCW selection (Table 1) were a combination of i) technical factors, i.e. organic load $>50 \%$ (as hydraulic load is generally already $>50 \%$ ), altitude $>650 \mathrm{~m}$, maturity of the VFCW (age from 2 to 10 years), and ii) different building companies.

Selected VFCW were of typically French design (directly fed with raw wastewaters), comprising a series of 2 successive vertical-flow filter stages as recommended by French guideline (Molle et al., 2005). Only Roffiac VFCW comprises 4 filters in the 1st stage and Mantet VFCW has no 2nd stage. All VFCW were fed directly with raw wastewater (coarsescreening only), in pulsed-batch doses. 


\begin{tabular}{|c|c|c|c|c|c|c|c|c|c|c|c|c|c|c|c|}
\hline \multirow[b]{3}{*}{$\underline{\text { Site }}$} & \multirow[b]{3}{*}{$\begin{array}{c}\text { Age in } \\
2014\end{array}$} & \multirow{2}{*}{\multicolumn{3}{|c|}{ General characteristics }} & \multicolumn{3}{|c|}{ Frozen conditions } & \multicolumn{4}{|c|}{$1^{\text {st }}$ stage } & \multicolumn{4}{|c|}{$2^{\text {nd }}$ stage } \\
\hline & & & & & \multicolumn{2}{|c|}{ Air min. temp. } & \multirow[b]{2}{*}{$\begin{array}{l}\text { Max. } \\
\text { consecutive } \\
\text { frozen } \\
\text { duration (d) }\end{array}$} & \multicolumn{2}{|c|}{ Filters } & \multicolumn{2}{|c|}{ Granulo. } & \multicolumn{2}{|c|}{ Filters } & \multicolumn{2}{|c|}{ Granulo. } \\
\hline & & $\begin{array}{l}\text { Capa. } \\
\text { (p.e.) }\end{array}$ & $\begin{array}{l}\text { Alt. } \\
(\mathrm{m})\end{array}$ & $\begin{array}{c}\text { Sewer } \\
\text { network }\end{array}$ & $\begin{array}{c}\text { Daily } \\
\text { minimal } \\
\left({ }^{\circ} \mathrm{C}\right)\end{array}$ & $\begin{array}{c}\text { Daily } \\
\text { average } \\
\left({ }^{\circ} \mathrm{C}\right)\end{array}$ & & $\begin{array}{c}\text { Area } \\
\left(\mathrm{m}^{2}\right. \\
/ \text { p.e. })\end{array}$ & $\begin{array}{c}1^{\text {st }} \\
\text { filtration } \\
\text { layer } \\
\text { depth }(\mathrm{m})\end{array}$ & $\mathrm{d}_{10}$ & $\mathrm{~d}_{60}$ & $\begin{array}{l}\text { Area } \\
\left(\mathrm{m}^{2}\right. \\
/ \text { p.e. })\end{array}$ & $\begin{array}{c}1^{\text {st }} \\
\text { filtration } \\
\text { layer } \\
\text { depth }(\mathrm{m})\end{array}$ & $\mathrm{d}_{10}$ & $\mathrm{~d}_{60}$ \\
\hline $\begin{array}{l}\text { St Pal de } \\
\text { Mons }\end{array}$ & 4 & 1900 & 780 & Mixture & -12 & -7 & 7 & 1.2 & 60 & 2.0 & 3.1 & 0.8 & 30 & 0.3 & 1.3 \\
\hline $\begin{array}{l}\text { St Just } \\
\text { Malmont }\end{array}$ & 3 & 500 & 790 & Mixture & -12 & -7 & 6 & 1.2 & 60 & 2.4 & 4.4 & 0.8 & 30 & 0.4 & 1.1 \\
\hline $\begin{array}{l}\text { Le Pont de } \\
\text { Montvert }\end{array}$ & 6 & 1500 & 860 & Separate & -11 & -7 & 4 & 1.2 & 40 & 3.0 & 5.7 & 0.8 & 40 & 0.4 & 1.8 \\
\hline Roffiac & 8 & 600 & 810 & Mixture & -17 & -7 & 5 & 1.3 & 30 & 1.5 & 3.7 & 0.9 & 30 & 0.3 & 1.1 \\
\hline Valette & 5 & 230 & 890 & Combined & -15 & -8 & 5 & 1.2 & 40 & 3.6 & 5.5 & 0.8 & 30 & 0.3 & 1.4 \\
\hline Orelle & 9 & 1200 & 835 & Separate & -11 & -7 & 5 & 1.0 & 60 & 3.0 & 5.4 & 0.8 & 30 & 0.3 & 2.5 \\
\hline $\begin{array}{l}\text { Le } \\
\text { Reposoir }\end{array}$ & 10 & 1200 & 980 & Separate & -19 & -10 & 7 & 1.3 & 30 & 4.6 & 10.3 & 0.7 & 40 & 0.2 & 1.1 \\
\hline Trescléoux & 2 & 600 & 680 & Combined & -13 & -8 & 3 & 1.3 & 25 & 2.1 & 3.1 & 0.7 & 30 & 0.2 & 0.8 \\
\hline Mantet & 3 & 73 & 1500 & Separate & -12 & -7 & 4 & 1.1 & 80 & - & - & - & - & - & - \\
\hline
\end{tabular}

\section{Table 1: General key characteristics of the VFCW treatment plants selected}

Table 1 presents the main plant characteristics. Samples of filter material were on the first $30 \mathrm{~cm}$ at each stage, then analysed for particle size distribution (French standard NF X 11.507, AFNOR, 1970) on raw (unwashed) dry material.

\section{Monitoring}

Daily hydraulic loads were recorded and collected by a pressure sensor placed in the feeding batches system (pumping station or siphon) of one of the filter stage. Recordings were taken at 1-minute intervals. Filter's alternation dates were noted by the operator. Two temperature sensors were installed at each VFCW: one outside $\left(\mathrm{T}_{\text {air }}\right.$, in $\left.{ }^{\circ} \mathrm{C}\right)$, and one inside the $1^{\text {st }}$ stage filter $\left(\mathrm{T}_{\text {filter, }}\right.$, in ${ }^{\circ} \mathrm{C}$, at $1.5 \mathrm{~m}$ from a feeding point and $15 \mathrm{~cm}$ deep). Recordings were taken at 15-minute intervals. The aim was to capture the range of temperature variation and their dynamic according to temperature gradient between in-filter and air temperatures.

\section{4-h flow composite samples}

The monitoring covered a 2-year period (2013-2014). One or two 24-hr flow composite samplings were done each winter in order to gauge the realistically-achievable cold-climate performances possible under different conditions of load, temperature, snowfall, etc. One 24$\mathrm{hr}$ performance assessment was done in summer (under optimal conditions) as a control comparing with the Irstea database (Morvanou et al, 2015). The objective was to gauge whether the selected VFCW were running properly in normal temperature conditions. The temperature controlled samplers $\left(4^{\circ} \mathrm{C}\right)$ were installed at the VFCW inlet and outlet of each stage. The chemical parameters analysed with standard method (APHA, 2012) were: $\mathrm{BOD}_{5}$, $\mathrm{COD}, \mathrm{SS}, \mathrm{TKN}, \mathrm{NH}_{4}-\mathrm{N}, \mathrm{NO}_{2}-\mathrm{N}, \mathrm{NO}_{3}-\mathrm{N}, \mathrm{TP}, \mathrm{PO}_{4}-\mathrm{P}$.

Four specific VFCW have been equipped for an additional monitoring. It consisted in:

- $\mathrm{pH}$, redox potential, conductivity, $\mathrm{NH}_{4}-\mathrm{N}$ and $\mathrm{NO}_{3}-\mathrm{N}$ (specific sensors VARION AN/A WTW-Secomam) online measurements at the inlet and outlet of each stage (1-minute step recording)

$-\mathrm{O}_{2}$ contents inside the air phase of the each filter (using a Dräger X-am $7000^{\circ}$ ) were measured in order to assess the aerobic conditions at several depths inside the porous media $(0$ to $40 \mathrm{~cm})$ at $2 \mathrm{~m}$ from a feeding point and $20 \mathrm{~min}$ after delivering a batch. 
Results are expressed as percent of the air phase $( \pm 0.2 \%)$. The objective was to not attribute a decrease of nitrification to temperature if aerobic condition was not present within the filer.

\section{RESULTS AND DISCUSSION}

The data collected over winter 2013 and winter 2014 were not significantly different (Student tests with a confidence of $95 \%$, see Table 2) on all parameters and were thus subsequently pooled. Summer-season performances were normal compared to expected removal (Molle $e t$ al., 2005), which validated the VFCW selection.

\section{Wastewater characteristics}

Inlet wastewater characteristics are presented in Table 2. No statistical difference is observed between each selected plant. In some cases, a slight dilution is observed in winter probably due to clear water intrusion into the sewer.

\begin{tabular}{|c|c|c|c|c|c|c|c|c|c|c|c|c|c|c|c|c|c|}
\hline $\begin{array}{l}\text { Wastewater } \\
\text { quality } \\
(\mathrm{mg} / \mathrm{L})\end{array}$ & \multicolumn{7}{|c|}{ Raw wastewater } & \multicolumn{5}{|c|}{$1^{\text {st }}$ stage outlet } & \multicolumn{5}{|c|}{$2^{\text {nd }}$ stage outlet } \\
\hline \multicolumn{18}{|c|}{ Winters 2013-2014 } \\
\hline Mean & 491 & 239 & 212 & 33 & 48 & 2,15 & 0,11 & 91 & 27 & 21 & 17 & 21 & 36 & 5 & 4 & 4 & 6 \\
\hline SD & 301 & 156 & 186 & 15 & 22 & 0,45 & 0,04 & 42 & 17 & 10 & 8 & 10 & 11 & 3 & 4 & 6 & 6 \\
\hline Max. & 1530 & 760 & 960 & 55 & 91 & 3,13 & 0,20 & 199 & 73 & 41 & 33 & 41 & 59 & 13 & 14 & 18 & 19 \\
\hline $\begin{array}{l}\text { Nbr of } \\
\text { values }\end{array}$ & 22 & 22 & 22 & 21 & 21 & 22 & 21 & 19 & 19 & 19 & 18 & 19 & 17 & 17 & 17 & 17 & 17 \\
\hline \multicolumn{18}{|c|}{ Summer 2013} \\
\hline Mean & 735 & 320 & 297 & 48 & 69 & 2,25 & 0,11 & 133 & 35 & 55 & 21 & 26 & 43 & 4 & 8 & 2 & 4 \\
\hline SD & 438 & 154 & 150 & 18 & 25 & 0,36 & 0,04 & 53 & 19 & 31 & 10 & 13 & 15 & 3 & 5 & 2 & 2 \\
\hline \multicolumn{18}{|c|}{ Difference between Winters and Summer: Student test } \\
\hline p-value & 0,09 & 0,14 & 0,15 & 0,03 & 0,02 & 0,48 & 0,93 & 0,03 & 0,22 & 0,00 & 0,30 & 0,19 & 0,18 & 0,68 & 0,03 & 0,10 & 0,22 \\
\hline \multicolumn{18}{|c|}{ Classical French values (Mercoiret et al, 2010; Molle et al, 2005) } \\
\hline Mean & 650 & 267 & 288 & 59 & 68 & 2.62 & 0.12 & 145 & - & 33 & - & 35 & 66 & - & 14 & - & 13 \\
\hline
\end{tabular}

Table 2: Influent and effluent characteristics

\section{Removal performances on BOD, COD and SS}

When looking at outlet concentrations of each stage (Table 2) and removal rates (Table 3, Fig. 1), we observe that outlet concentrations remained excellent regardless of season, although measured peaks were higher in winter for the $\mathrm{COD}, \mathrm{BOD}_{5}$ and nitrogen parameters, which points to a possible weakness in system reliability when conditions are less conducive to biodegradation. However, Winter-season removal performances were very good overall and were consistent with observed conventional-system removal performances (Molle et al., 2005). 


\begin{tabular}{|c|c|c|c|c|c|c|c|c|c|c|c|c|c|c|c|}
\hline \multirow{2}{*}{$\begin{array}{l}\text { Removal } \\
\text { rate (\%) }\end{array}$} & \multicolumn{5}{|c|}{$1^{\text {st }}$ stage } & \multicolumn{5}{|c|}{$2^{\text {nd }}$ stage } & \multicolumn{5}{|c|}{ Global } \\
\hline & COD & $\mathrm{BOD}_{5}$ & SS & $\mathrm{NH}_{4}-\mathrm{N}$ & $\mathrm{TKN}$ & COD & $\mathrm{BOD}_{5}$ & SS & $\mathrm{NH}_{4}-\mathrm{N}$ & TKN & COD & $\mathrm{BOD}_{5}$ & SS & $\mathrm{NH}_{4}-\mathrm{N}$ & TKN \\
\hline \multicolumn{16}{|c|}{ Winters 2013-2014 } \\
\hline Mean & 77 & 85 & 86 & 40 & 52 & 60 & 82 & 81 & 78 & 77 & 91 & 98 & 97 & 85 & 87 \\
\hline SD & 9 & 7 & 9 & 17 & 14 & 8 & 8 & 13 & 21 & 16 & 4 & 2 & 2 & 15 & 12 \\
\hline Min. & 57 & 70 & 57 & 4 & 13 & 47 & 62 & 46 & 20 & 42 & 82 & 94 & 93 & 51 & 58 \\
\hline Max. & 93 & 96 & 97 & 70 & 76 & 72 & 91 & 92 & 99 & 96 & 98 & 100 & 100 & 99 & 99 \\
\hline $\begin{array}{l}\text { Nbr of } \\
\text { values }\end{array}$ & 22 & 22 & 22 & 21 & 21 & 17 & 17 & 17 & 17 & 17 & 17 & 17 & 17 & 17 & 17 \\
\hline \multicolumn{16}{|c|}{ Summer 2013} \\
\hline Mean & 79 & 88 & 80 & 58 & 62 & 68 & 87 & 85 & 89 & 84 & 94 & 99 & 97 & 96 & 94 \\
\hline SD & 7 & 4 & 11 & 14 & 14 & 10 & 9 & 11 & 12 & 11 & 3 & 1 & 1 & 4 & 4 \\
\hline Min. & 69 & 80 & 61 & 37 & 32 & 52 & 67 & 58 & 67 & 66 & 87 & 95 & 95 & 89 & 90 \\
\hline Max. & 91 & 94 & 94 & 85 & 83 & 86 & 97 & 94 & 100 & 96 & 98 & 100 & 100 & 100 & 99 \\
\hline $\begin{array}{l}\text { Nbr of } \\
\text { values }\end{array}$ & 13 & 13 & 13 & 11 & 13 & 11 & 11 & 11 & 11 & 11 & 11 & 11 & 11 & 10 & 11 \\
\hline \multicolumn{16}{|c|}{ Difference between Winters and Summer: Student test } \\
\hline $\mathrm{p}$-value & 0,48 & 0,15 & 0,11 & $<0,01$ & 0,05 & 0,05 & 0,14 & 0,41 & 0,10 & 0,19 & 0,08 & 0,11 & 0,88 & 0,01 & 0,04 \\
\hline \multicolumn{16}{|c|}{ Classical French values (Molle et al, 2005) } \\
\hline Mean & 79 & - & 86 & - & 58 & 56 & - & 65 & - & 71 & 91 & - & 95 & - & $>85$ \\
\hline
\end{tabular}

\section{Table 3: Treatment performances}

Performances appeared to dip slightly in winter compared to summer, particularly on the $2^{\text {nd }}$ stage where summer-season removal performances outstripped winter-season performances by 8 and 5 points on $\mathrm{COD}$ and $\mathrm{BOD}_{5}$, respectively. However, all in all, this negative impact is downplayed, as any effective performance gain is i) impossible to confirm due to high standard deviations, and ii) no longer visible on the VFCW's aggregate performance balance. In fact, statistical Student test shows no significant differences between winters and summer (Table 3, p-values > 0.08 for $\mathrm{COD}, \mathrm{BOD}_{5}$ and $\mathrm{SS}$ for global treatment). The differences on total removals seem to be very low on those parameters regarding the means and the confidence intervals. As a rule, then, cold temperatures do not appear to impact ability to treat the classic organic and suspended solids parameters.
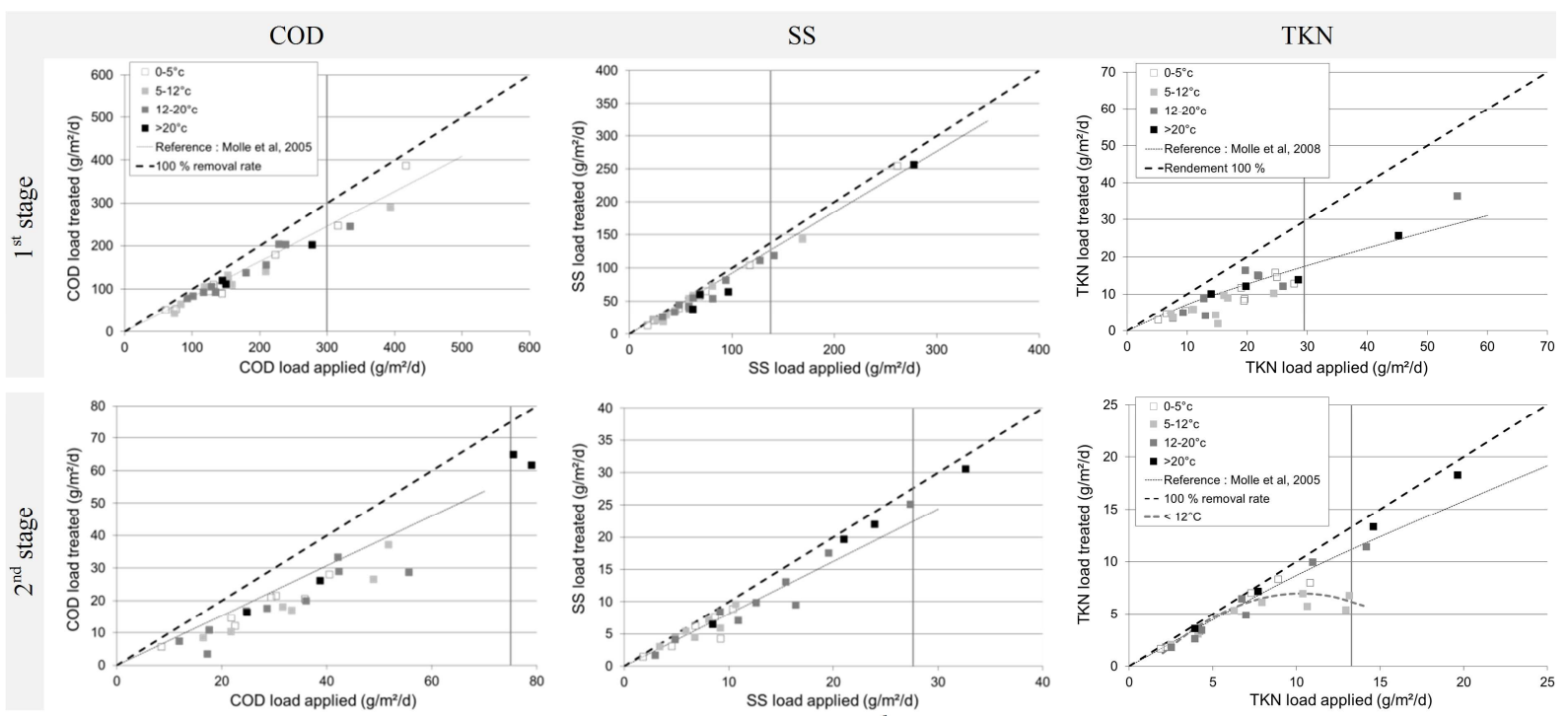

Figure 1: COD and SS load treated on the $1^{\text {st }}$ and $2^{\text {nd }}$ stages

\section{Nitrogen removal capabilities}

Gas measurements

Oxygen measures done (not shown) during monitoring confirmed that no oxygen limitation is present when alternation is done every 3-4 days. This is consistent with measures recorded on 
other treatment plants in both winter and summer (Molle et al., 2008), which therefore rules out oxygenation issues in the VFCW surveyed here.

\section{4-h flow composite samples}

The results (Table 3 and Fig. 1) are very close to the figures reported by Molle et al. (2005, 2008). For the first stage, no significant difference can be done according to filter's temperature. This observation can be linked to the insulation effect of the deposit layer that forms at the top surface. This point is discussed in the insulation part.

On the second stage, removal performances proved visibly lower in winter than in summer only for loads above around $10 \mathrm{~g} / \mathrm{m}^{2} / \mathrm{d}$. It thus emerges that nitrification performances are relatively slightly affected during the winter season (see Table 3). Winter-season TKN removal performances tended to dip slightly for hydraulic loads over the design load $(>0.37$ $\mathrm{m} / \mathrm{d}$, not shown).

There is recurrent variability in nitrification as it is tied to different factors as the hydraulic (preferential flows), the feeding day of the feeding period (oxygen content), adsorption capacity of the filter (Morvannou et al., 2014), thus the age of the system, which can induce concomitant impact with temperature. As there is no deposit layer on the second stage, it is more sensitive than the first one to temperature losses. The TKN and NH4-N averages of total global removal rates confirm the slight difference between winter and summer yields, and pvalue is low ( 0.04 for TKN total removal). Nevertheless, nitrification performances of the whole system are good whatever the temperatures: confidence intervals $(95 \%, \mathrm{CI}=$ mean \pm $2 x \mathrm{SEM})$ of mean removal rates in winter and in summer seasons are $[82 ; 93]$ and $[92 ; 96] \%$ respectively.

This trend warrants confirmation through further complementary data but is confirmed when studying only winter data into two groups $\left(T_{\text {filter }}<6^{\circ} \mathrm{C}\right.$ and hydraulic load $>0.37 \mathrm{~m} / \mathrm{d}$; scenario $1 ; \mathrm{n}=5$ as one subgroup against the other winter data as scenario $2 ; \mathrm{n}=16$ ) (see Fig. 2 , left). Scenario 1 is the most challenging situation yet is visibly liable to be encountered a quarter of the time in winter.
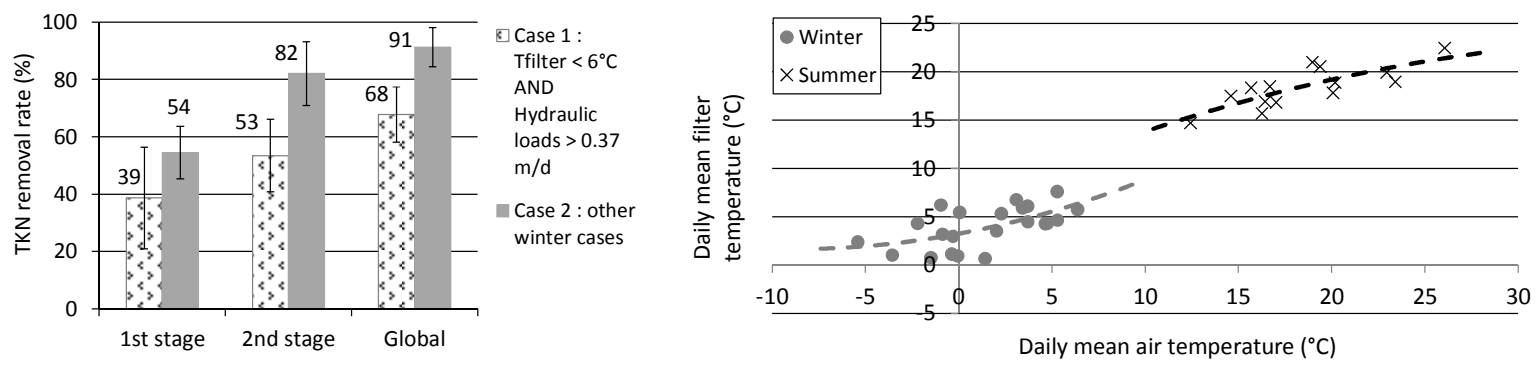

Figure 2: TKN removal rate under worst-case conditions (left) and Daily mean filter temperature $\left(1^{\text {st }}\right.$ stage) vs daily mean air temperature (right)

\section{Thermic insulation of the filter}

As we observed that nitrification can be affected by very low filter's temperature, it is relevant to discuss the dynamic of temperature within the filter and its thermal insulation.

\section{Inside temperature-outside temperature linkage}

The linkage between $\mathrm{T}_{\text {air }}$ and $\mathrm{T}_{\text {filter }}$ is established in Fig. 2 (right) for the 38 24-hr performance assessments. Over the course of this study, even when daily mean air temperature was below freezing (down to $-6^{\circ} \mathrm{C}$ ), none of the filters iced up. The effluent appears to maintain a degree of warmth inside the filter matrix. 
217 To highlight how filter can buffer air temperature variation, the following Fig. 3 plots, on left, 218 the difference between daily mean filter and air temperature versus daily mean air temperature 219 and, on right, the loss of daily mean filter temperature per day according to the difference 220 between daily mean filter and air temperature. These figures are to be read and interpreted as 221 set out below. As each point corresponds to a daily mean temperature, it does not reflect the range of extremes in variation observable within a day. 


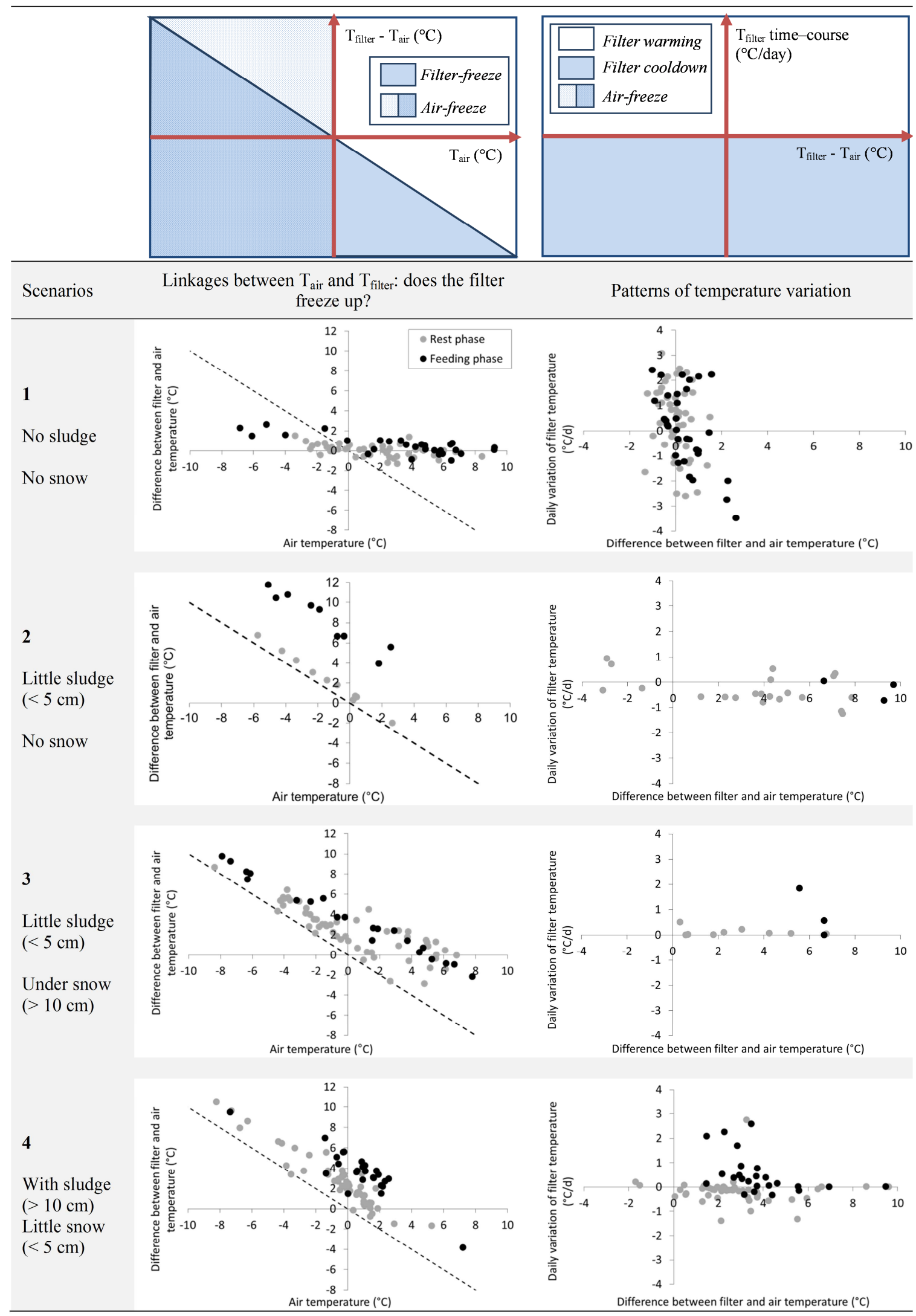

Figure 3: Linkages between daily mean $T_{\text {air }}$ and $T_{\text {filter }}$ (does the filter freeze up?) and Patterns of temperature variation

Scenario 1: no sludge and no snow 
The absence of snow and sludge on the top of the filter fails to insulate the filter, which is highly sensitive to plummeting outside temperatures. As soon as there is frost in the air (down to a mean daily temperature of $-7^{\circ} \mathrm{C}$ ), the temperature inside the filter drops simultaneously down to $-5^{\circ} \mathrm{C}$. This case happens at the beginning of a plant operation or when the load is too low to favour deposit accumulation. Consequently, the sensitivity of the filter is reinforced by the fact that water distribution is not homogeneous. In this case, the temperature probe wasn't in contact with wastewater. No difference was noted between feeding and rest periods. Hydraulically it is not problematic as filter does not freeze where wastewater infiltrates during feeding period.

\section{Scenario 2: little sludge $(<5 \mathrm{~cm})$ and no snow}

As soon as a deposit layer is present, wastewater distribution is optimized and a reel difference exists between feeding and rest periods. The warmth of the wastewater allows to warm up the filter. During resting periods, the low level of deposit cannot insulate a lot the media and loss of around $0.6^{\circ} \mathrm{C} / \mathrm{d}$ until 8 degrees of difference between daily mean air and filter temperature. It confirms the benefit of a twice-weekly rotation regime in order to prevent prolonged periods of heat loss during rest periods.

\section{Scenario 3: little sludge $(<5 \mathrm{~cm})$ and under snow $(>10 \mathrm{~cm})$}

Compared to scenario 2, an additional snow layer allows a better insulation. With $15 \mathrm{~cm}$ of snow cover measured at the VFCW surface, the resting filter buffers extremely well $(+1$ to $+2^{\circ} \mathrm{C}$ ) despite sharp drops in daily mean $\mathrm{T}_{\text {air }}$ (until $-12^{\circ} \mathrm{C}$, and down to $-7^{\circ} \mathrm{C}$ for 3 days in a row).

\section{Scenario 4: with sludge ( $>10 \mathrm{~cm})$ and practically no snow $(<5 \mathrm{~cm})$}

When the accumulated sludge layer is relatively deep $(>10 \mathrm{~cm})$ a high insulation capacity is observed. For all cases studied, even when daily mean air temperature was low $\left(-10^{\circ} \mathrm{C}\right)$, none of the filters iced up. Up to $8^{\circ} \mathrm{C}$ difference between daily mean air and filter temperature, the filter effectively buffered (almost no drop in filter temperature) and filter temperature stayed over zero $\left(+2\right.$ to $\left.+3^{\circ} \mathrm{C}\right)$ in resting period.

\section{Design characteristics and operational constraints vs cold climate}

The insulating effect of snow and deposit layer, show the necessity to favour their presence. Consequently the question of implementing a compost layer at the construction could improve insulation problems observed when deposit layer is not yet formed. It is often fears that snow would melts during feeding and then reduces filter insulation. We observed that the warmth embodied in the effluent quickly thaws the snow only near the feeding points. Then the snow melts from the bottom as water flows below the snow. It is thus of importance to not favour high ponding to keep snow from melting. Consequently, it is better to alternate twice a week the filter than once a week.

\section{CONCLUSIONS AND RECOMMENDATIONS}

This study allowed observing that French VFCWs do not face to big trouble when installed in mountain areas. Over-winter treatment performances on COD, $\mathrm{BOD}_{5}$ and SS are not visibly impacted by cold-season temperatures, and indeed prove excellent on a level similar to summer-season figures, with more than $90 \%$ of removal over the two stages for these parameters.

Nitrogen treatment, which is sensitive to temperature conditions, was studied in greater detail. While oxygen content was not limited to nitrification, there is a drop in nitrification when filter temperature is below $6{ }^{\circ} \mathrm{C}$. Winter-season nitrification performances (TKN) average out 
at $87 \%$, against $94 \%$ in the summer season. However, nitrification is mainly affected at the second stage when loads are above $10 \mathrm{gTKN} / \mathrm{m}^{2} / \mathrm{d}$. That said, VFCW serving mountain-area communities, perform globally well on TKN treatment.

These performances observations are linked to different aspects as the effluent capacity to deliver enough embodied warmth to hold feed-phase filter temperatures at around $+5^{\circ} \mathrm{C}$, as well as the insulation capacity of snow and the deposit layer. Indeed, even for small deposit layer a small loss of $0.6^{\circ} \mathrm{C}$ per day is measured during rest period. When the deposit layer is above $10 \mathrm{~cm}$ no loss is measured and filter temperatures stay higher than +1 to $+2^{\circ} \mathrm{C}$.

As this insulation effect must have a limit, it is of importance to minimize heat losses by design adaptation and operation. For VFCW design, there are a number of evident commonsense rules, such as sitting on an aspect that receives direct sun and burying all filter-feeding pipework plus any valves and access hatches as deep into the ground as possible. There are also practical considerations to factor in-operatives will often struggle to get to mountainarea VFCW in adverse weather events (snowfall, rockslide, landslip), which means accessways should ideally be designed-in. In terms of operation, alternate twice a week the filter is strongly recommended. The rationale is to minimize the risk of freeze-up, especially on less mature VFCW ( $<5$ years old) where the sludge layer has not had the time to grow high enough. The question of using automatic alternation is then of importance as operators can have some problem to be present.

\section{ACKNOWLEDGEMENTS}

The authors thank the Rhône-Méditerranée-Corse, Adour-Garonne and Loire-Bretagne water authorities for providing financial support, the Hautes-Alpes, Ardêche/Drôme, Cantal, HauteLoire, Lozère, Pyrénées-Orientales, Savoie, and Haute-Savoie département local technical services (SATESE) for their help with the provision of data, and all the communities involved in this study for their cooperation.

\section{REFERENCES}

AFNOR (1970). Analyses granulométriques : Tamisage de contrôle, NF X 11-507. Normalisation Française, 2e Ed, 60-75.

Bronfenbrener L., Bronfenbrener R. (2010). Modeling frost heave in freezing soils. Cold Regions Sci. Tech., 61, 43-64.

Kadlec R.H. (2001). Thermal environments of subsurface treatment wetlands. Wat. Sci. Tech., 44(11-12), 251-258.

McCarthy B., Axler R., Monson-Geerts S., Henneck J., Crosby J., Nordman D., Weidman P., Hagen T. (1997) Development of Alternative On-site Treatment Systems for Wastewater Treatment: A Demonstration Project for Northern Minnesota: Final Report Submitted to Minnesota Technology Inc., Legislative Commission for Minnesota Resources, Electric Research Power Institute. Natural Resources Research Institute, University of Minnesota, Duluth, Minnesota.

Mercoiret L. (2010) Qualité des eaux usées domestiques produites par les petites collectivités : Application aux agglomérations d'assainissement inférieures à 2000 Equivalent Habitants. Domestic wastewater characteristics from communities of less than 2,000 People Equivalent, 55p. Website: http://epnac.irstea.fr.

Molle P., Liénard A., Boutin C., Merlin G., Iwema A. (2005). How to treat raw sewage with constructed wetlands: an overview of the French systems. Wat. Sc. Tech., 51(9), 11-21.

Molle P., Prost-Boucle S., Liénard A. (2008). Potential for total nitrogen removal by combining vertical flow and horizontal flow constructed wetland: A full-scale experiment study. Ecol. Eng., 34(1), 23-29. 
328 Morvannou A., Choubert J.-M. Vanclooster M., Molle P. (2014) Modelling nitrogen removal 329 in a vertical flow constructed wetland treating directly domestic wastewater. Ecol. Eng., 70, $330 \quad 379-386$.

331 Morvanou A., Forquet N., Michel S., Troesch S., Molle P. (2015) Treatment performances of 332 French constructed wetlands: results from a database collected over the last 30 years. Wat. 333 Sci. Tech., in press (doi: 10.2166/wst.2015.089)

334 Prost-Boucle, S., Molle, P. (2012). Recirculation on a single stage of vertical flow constructed wetland: Treatment limits and operation modes. Ecol. Eng., 43, 81-84.

336 Smith I. D., Bis G. N., Lemon E. R., Rozema L. R. (1997). A thermal analysis of a subsurface Vertical Flow Constructed Wetland. Wat. Sci. Tech., 35(5), 55-62.

338 Wallace S., Parkin G., Cross C. (2011). Cold climate wetlands: design and performance. Wat. 339 Sci. Tech., 44(11-12), 259-265. 